\title{
LEPROSY IN NORWAY
}

by

\author{
TH. M. VOGELSANG
}

WE do not know when leprosy invaded Norway, nor where it came from. It seems most probable that the disease spread from the British Isles in Viking times. The Norwegian Vikings were in active contact with the other North Sea people, and had settlements in Ireland, the Scottish Islands, the Faroe Islands, Iceland and Greenland. The Vikings brought home not only goods and gold, but also captives of both sexes. Irish women are said to have been especially attractive to the Norwegian Vikings, and it is known that as early as the tenth century leprosy was widespread in Ireland. Indeed the first recorded leper hospital in the British Isles was founded in Ireland in about the seventh century. ${ }^{1}$ It appears that the Norsemen knew and feared the disease: 'At home in Denmark and Norway nobody had as yet founded hospitals for the lepers, but in England and especially in Ireland, the Norsemen had learnt to look at leprosy as a horrible disease which they had to combat with all their might and main. In 921 when King Gudröd of Dublin plundered Armagh in Ulster he spared, as the Irish Year Books state, "the houses of the prayer where the men of God and the lepers stayed".'2 Soon after these leper hospitals were founded in the Viking settlements around the Irish Sea. In the south of Cumberland on the Furness peninsula is a place called Loppergarth. Traditionally there was a leper hospital here which was probably of Norse origin. Loppergarth is a Nordic name derived from Lobragaard - the first syllable being the old Irish 'lobran' (Gaelic 'lobbrar') meaning sick, especially leprous, while the last syllable is the Norwegian word for a house.

When we consider the cruelty and the violence of the Vikings on their raids, it is apparent that it was not from pity that they spared 'the houses of prayer where the men of God and the lepers stayed' in Armagh. It was surely more likely that they had a horror of the shocking appearance of the lepers and were afraid of being infected themselves. The Vikings, however, had no knowledge of the long incubation period and the insidious start of the disease. They, therefore, did not have enough knowledge to prevent the spread of the disease to other Viking settlements or to their native country.

Scotland was affected later than Ireland. ${ }^{3}$ If, as is suggested, the name Liberton is a conversion of 'Lepertown', it would seem that leprosy must have been known in the reign of David I of Scotland, who died in I I 53, for Liberton is mentioned in various charters of his reign. From Ireland and Scotland the knowledge of the care of the lepers spread to the Faroe Islands. On the South Island there is a bay called Lobbra where there is supposed to have been a leper hospital in the Middle Ages.

A disease like leprosy must be well established before it is subject to legislation. But in the oldest Norwegian laws, Gulathing's and Borgarthing's Law, it is stated that a promise of marriage was not binding if one of the partners was 


\section{Th. M. Vogelsang}

found to be leprous, and lepers were exempt from military service. These facts lead us to believe, with reasonable certainty, that leprosy was fairly common in Norway by about A.D. 1000 .

In the Middle Ages it was the clergy and the conventuals who undertook the care of the sick, and most of the hospitals were therefore connected with a church or a monastery. The oldest hospital known in Norway was founded in Nidaros (at present Trondheim) in the twelfth century and was connected with the cathedral.4 It is clear from an old document that it received ordinary patients as well as lepers. In the next century two new hospitals were founded in Nidaros, one for men and the other for women. They formed a joint institution and as late as in the middle of the last century they still had fifteen lepers.

The Norwegian Vikings who raided Ireland and Scotland were mostly from western Norway, where conditions favoured the rapid spread of leprosy. Most of our knowledge of the disease in Norway in the Middle Ages is in connection with the history of Bergen and the leper hospitals there. ${ }^{5}$

After a big fire in Bergen in 1248, King Håkon Håkonsön decided to rebuild some of the burnt churches. Among these was All-Saints' Church in the centre of Bergen which he decided should be attached to a hospital, Ospitale pauperum apud omnes sanctos, and Saint Catharine's Church which should be attached to a leper hospital, Ospitale sancte Chatherine leprosorum. We do not know for how long lepers were received in these hospitals. All-Saints' Hospital fell into decay

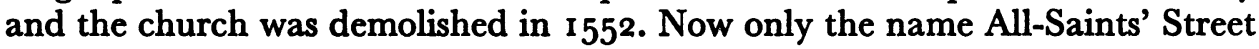
is left as a memory of old magnificence.

Saint Catharine's Hospital was mentioned as late as the sixteenth century as a leper hospital, but at the end of the same century it was taken over by the 'Office'; that is, that part of Bergen which was inhabited by the Hanseatic merchants.

In the thirteenth century leper hospitals were also founded in Stavanger, Tönsberg and Oslo, and inland at Hamar. During this century leprosy spread throughout Europe. Nearly two thousand leper hospitals existed in France, and at the same time it is said that there were more than three hundred in Great Britain. In Scotland leper hospitals were in existence as far back as the twelfth century.

As early as about II 70 a leper hospital was founded at Kalundborg in Denmark, ${ }^{6}$ and in what is now Sweden a leper hospital was founded at Lund about the year $1200 .^{7}$

As in most of west and southern Europe the leper hospitals were dedicated to St. Lazarus; it is not easy to explain why the Scandinavian countries should have chosen to associate St. George with the lepers. He was presumably chosen as patron in memory of his victory over the dragons, which perhaps symbolized the lepers' victory over the disease. ${ }^{8}$ Of all the Norwegian hospitals the hospital called St. Jörgen's Hospital in Bergen (St. George's Hospital) can give us the most copious information. ${ }^{5}$ It is mentioned in a will of $14 \mathrm{II}$. In an old document it is called 'The Spital in the Field'. As a result of the fires which throughout the ages have devastated the wooden residences of Bergen, St. Jörgen's Hospital has several times disappeared in the flames, but each time 


\section{Leprosy in Norway}

has been rebuilt on the same site. As Bergen has expanded 'The Field' has become a more and more central part of the town, and St. Jörgen's Hospital is today more or less in the middle of town, a stone's throw from the railway station.

From the fifteenth century leprosy declined in Norway as in the other European countries. By the end of the sixteenth century the disease had almost completely disappeared in southern Norway and the inland areas.

Originally the St. Jörgen's Hospital in Bergen was founded only for lepers from Bergen, but later non-infected individuals were received. The decrease in the incidence of the disease led to the relaxing of precautions, and the disease again appeared in those parts of the country where it had not been completely eradicated. This was the case not only in Bergen, but all along the west coast of Norway. The result was that lepers from all the coastal districts were received at St. Jörgen's Hospital. The part of the hospital where the lepers lived was demolished in I yor and a new building constructed, partly because the old building was scattered and partly because it was too small. About a year after the reconstruction of the new building, a big fire broke out in Bergen and laid great parts of the town in ashes. St. Jörgen's Hospital was totally destroyed in the flames. The hospital was, however, immediately rebuilt, but so badly that in 1847 it was necessary to make considerable alterations and to allot additional space to the steadily increasing number of lepers.

These old buildings and the adjacent wooden church still exist in Bergen. They give a good expression of the poor conditions under which the lepers lived in their humble walks of life. There are two kitchens in the centre of the hospital building and on either side of these a workroom which also functioned as living- and dining-rooms. Surrounding these two rooms there are several small cellular rooms which served as sleeping apartments. The cells were not heated, but stoves were placed in the two working rooms. In the largest wing on the ground floor and in the gallery there were forty cells for eighty lepers, and in the other wing sixteen cells for thirty-two old people. The cells are all the same size, about seven feet wide and six feet long. They each have their own entrance from the workroom. The cells were usually inhabited by two individuals, and had a small bed on each side with a narrow gangway between. Welhaven, the chaplain to the hospital in 1816 , gives a vivid picture of the conditions in the hospital. ${ }^{\circ} \mathrm{He}$ pointed out that conditions would have to be improved if the hospital were not to continue to be a graveyard for the living. The lepers themselves were to contribute to their livelihood by making shoes, matches, knives, spoons, etc. Up to 189 I they went from house to house with their merchandise and sold them at the market-place in Bergen. But from this year their market trade was stopped and their previously free movement in the town was limited.

In 18 I 7 , for the first time, a physician was attached to the hospital, ${ }^{10}$ but reforms did not occur until D. C. Danielssen started his work there. He was born in Bergen in 1817 , the son of a watchmaker. ${ }^{11}$ His parents were poor, so when he was only thirteen he had to take employment as a pupil in a pharmacy. At seventeen he developed tuberculosis of the hip-joint which tied him to his 


\section{Th. M. Vogelsang}

bed for a year and a half and which left him permanently lame. During his long illness he prepared himself for the student examination. When he was twenty he passed this examination and only three years later, in 1832 , he obtained the highest marks as examinatus medicinae in Oslo, a medical qualification which was of lower degree than the ordinary medical one. He returned to Bergen in I839 and stayed there for the rest of his life until his death in 1894. Back in Bergen he immediately started his scientific investigations on leprosy, while at the time engaging in other studies of natural sciences. He was a member of the Board or the Council, the founder of several societies of public utility and safety and also member of several state committees. In 1847, together with the later professor of dermatology, Carl Wilhelm Boeck, he published the great work Om Spedalskhed (On Leprosy) which led Bergen to be regarded for many years as the European centre for leprosy research. It was the first scientific work which gave not only an important description of facies morbi, but also of the pathological anatomy of leprosy. One year later a French edition was published in Paris. The work was accompanied with a large atlas of paintings of leprous cases. In I948, a century later, de Souza-Araujo of Rio de Janeiro, published a facsimile reproduction of this atlas. In a preface he mentions the two scientific men as 'les vrais fondateurs de la moderne leprologie'.

Scabies was a very common disease of the lepers, occurring in a particularly disgusting form, quite different from the usual appearance. In their atlas Danielssen and Boeck have two plates showing this disease which was called Scabies crustosa, but later-annoyingly enough-Scabies Norwegica.

At the time of the first reliable census of lepers in Norway taken in 1856 , a total of 2,858 lepers was reported. Norway had at that time a population of about one-and-a-half million, so that about two per thousand of the inhabitants were lepers. They were largely confined to coastal districts and were particularly numerous, up to twenty-five per thousand, around Bergen. This increase in the number of lepers in the middle of the last century caused the authorities to take more stringent precautions against any further spread. In 1849 the Lungegården hospital in Bergen was opened as a leper hospital. It was a large wooden building with room for eighty-four lepers, but the whole building burnt down on Christmas night 1853 and six lepers and one servant lost their lives. The hospital was immediately rebuilt, this time a solid stone building, designed for ninety-six lepers. In the following years some other leper hospitals were brought into use, so that more than eight hundred lepers could be hospitalized.

The basis of the precautions taken against the spread of leprosy during these years was the belief that leprosy was an hereditary disease. A change in this view came in 1868 when Armauer Hansen was attached to the leper hospitals in Bergen. He quickly came to the conclusion that leprosy was a specific disease which must have a specific cause. On the basis of this conception he worked indefatigably and insistently until he succeeded in finding the causative agent of the disease.

Gerhard Henrik Armauer Hansen was born in Bergen in 1841. He was eighth in a family of fifteen, of whom ten were boys. Most of them, both the boys and the girls, later reached important positions in Norwegian society. As a medical 


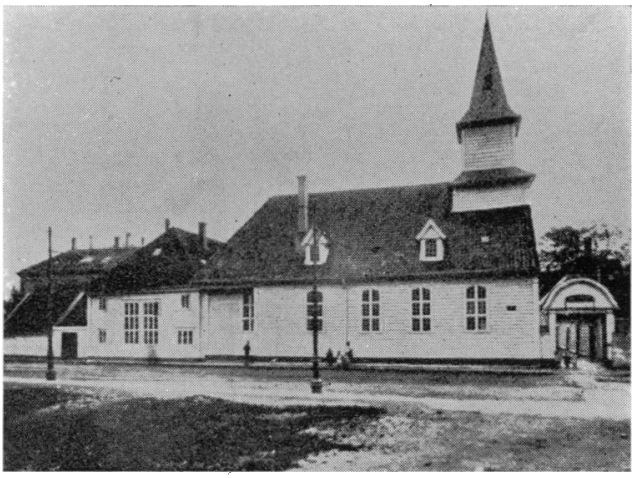

Fig. I. St. Jörgen's Hospital in Bergen and the adjacent wooden church.

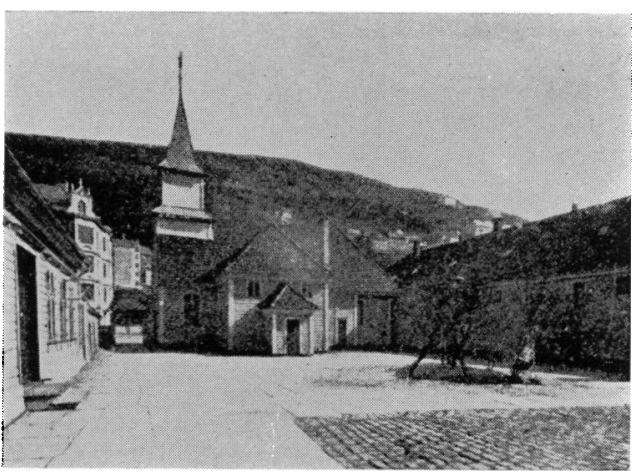

Fig. 2. The court-yard of St. Jörgen's Hospital. The hospital to the right and the chaplain's residence to the left.

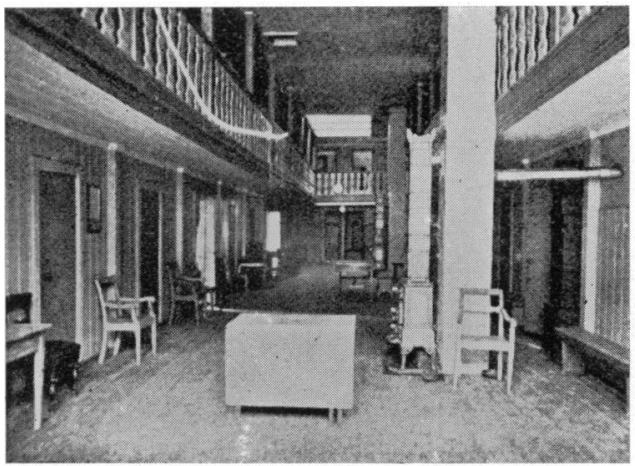

Fig. 3. The living- and dining-room surrounded by the sleeping quarters on the ground floor and the gallery.

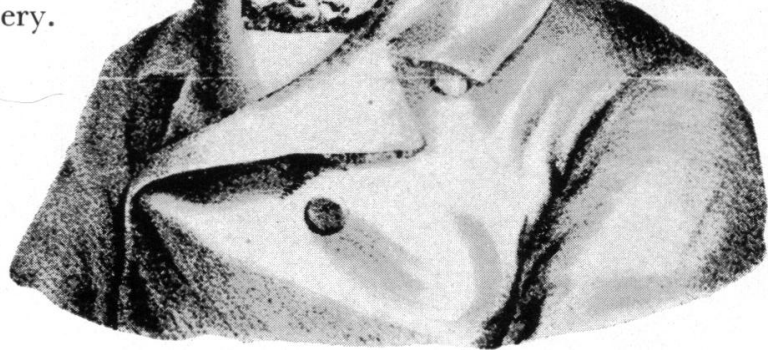

Fig. 4. Daniel Cornelius Danielssen (1815-94). 

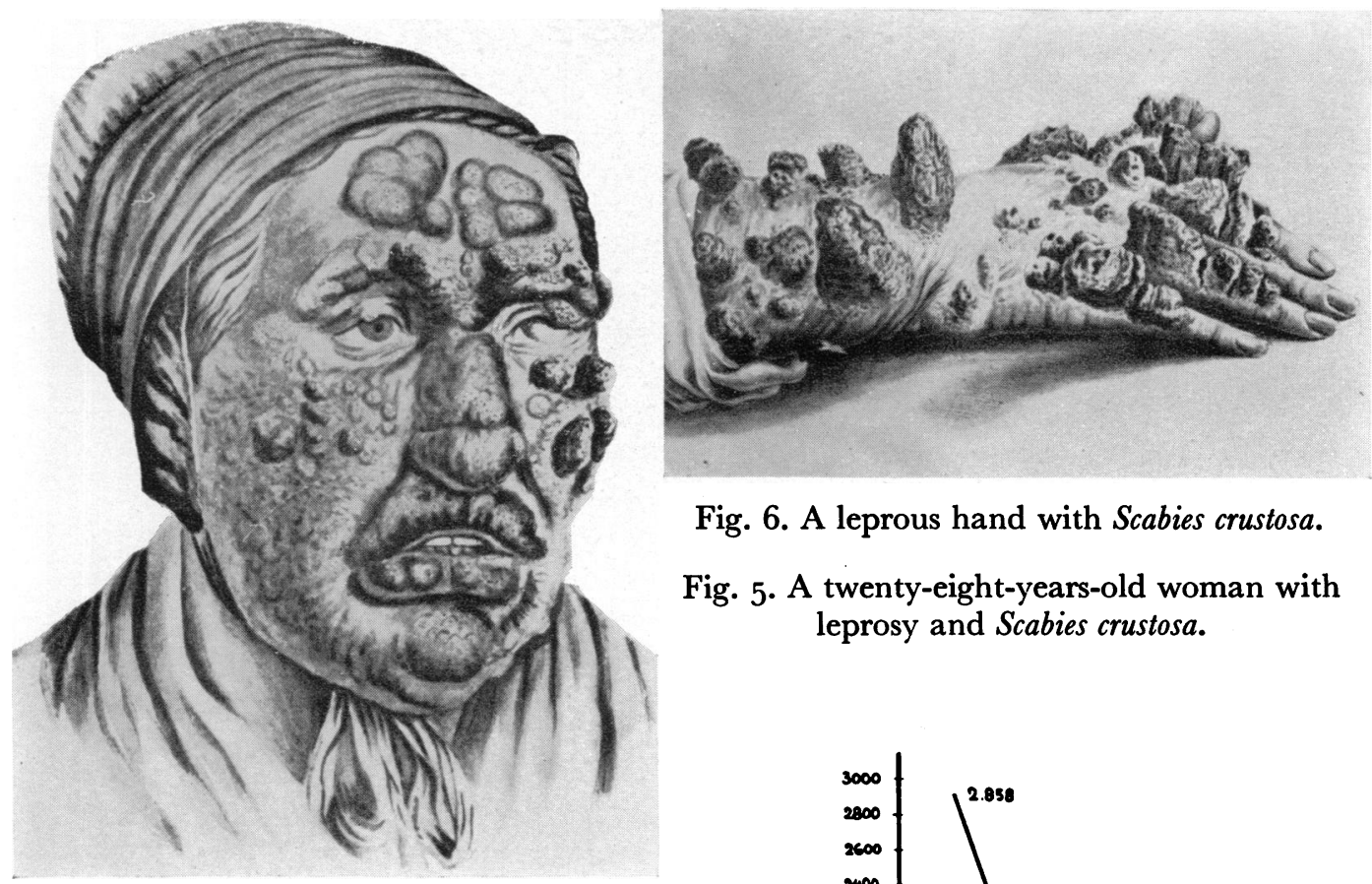

Fig. 6. A leprous hand with Scabies crustosa.

Fig. 5. A twenty-eight-years-old woman with leprosy and Scabies crustosa.
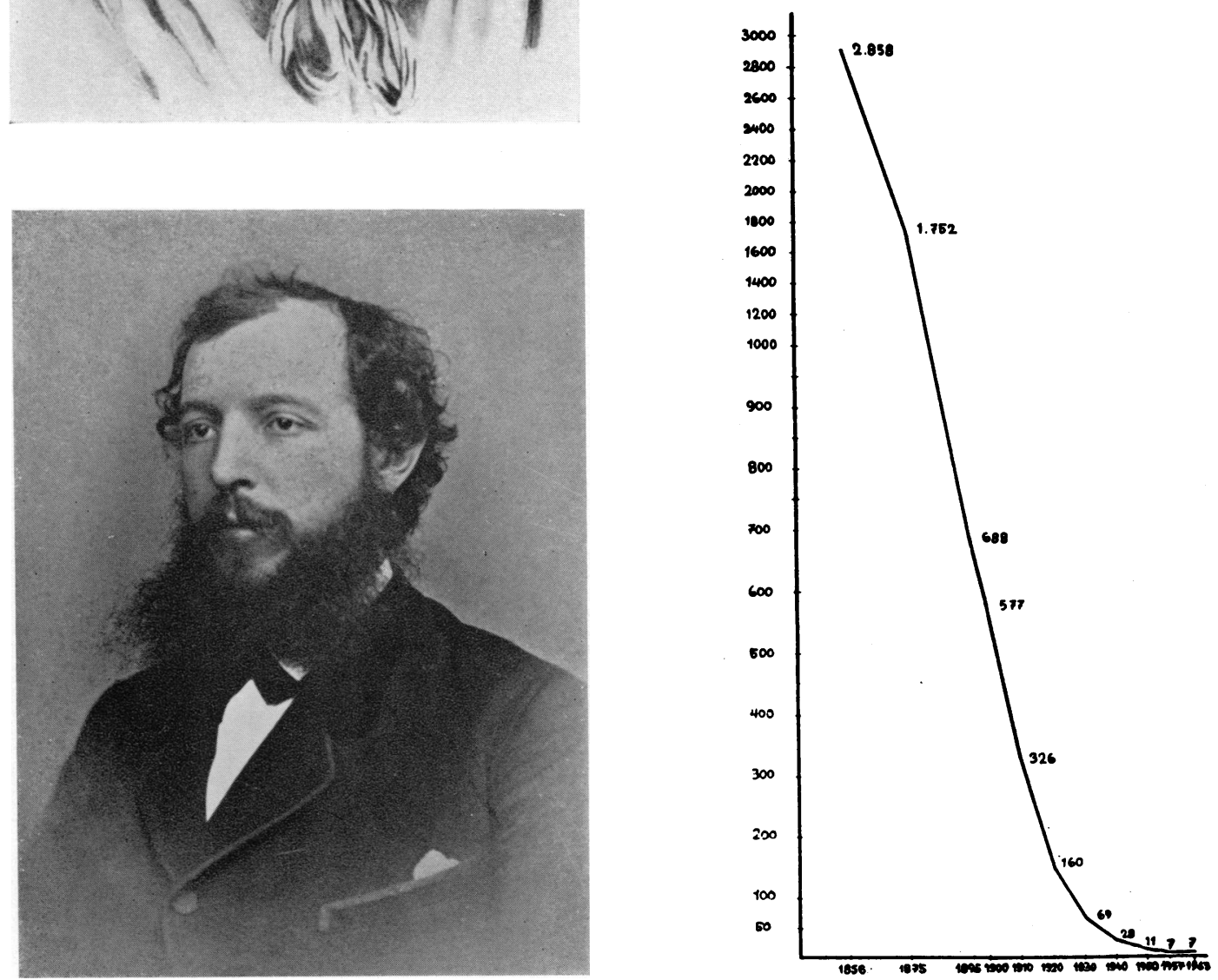

Fig. 7. Gerhard Henrik Armauer Hansen (c. 1873).

Fig. 8. Number of lepers in Norway (1856-1963). 


\section{Leprosy in Norway}

student Armauer Hansen, as he said himself, never tired, but worked hard to satisfy his pleasure in research. As an old man he pointed out that it is this need to discover which forces a student to research work and induces him to have more trust in his own observations than in the teaching of his instructors. When he was first attached to the leper hospitals, he suffered greatly from seeing so much misery centred at the same place. Gradually, however, when he put his fingers on the lepers for examination, this feeling of disgust disappeared and in its place grew an increasing interest in learning more and more about the disease.

His first scientific publication was an investigation of the normal and pathological anatomy of the lymph nodes. ${ }^{12}$ Among these nodes there were also some leprous ones in which he observed yellowish granular masses. Following up this observation he found the same granular masses in nodules from other leprous organs also and came to the conclusion that they must be specific for leprosy. This view was in conflict with that of his chief, D. G. Danielssen, who throughout his whole life regarded leprosy as a hereditary disease of the blood, dyscrasia sanguinis. However, it is characteristic of his open mind and his sense of science that nobody was keener than Danielssen in encouraging, even inspiring, Armauer Hansen to try to prove his theory.

In 1871 Hansen was given a grant by the Norwegian Medical Society in Oslo (at that time Christiania) to study leprosy. The report of his research work, containing his classical description of the leprosy bacillus, was presented to the society in 1873 . The council found the report so important that it was published in the medical journal of the society as a separate number in $1874^{13}$

Bacteriology was at that time in its infancy. After very primitive staining with osmic acid, Armauer Hansen succeeded in demonstrating the rod-shaped bodies which are the causative agent of leprosy. He describes them as rods which 'are partly found together in bundles, crossing one another at very sharp angles'. He finishes his report with the following thesis: 'I have now prepared my topic from all aspects which I at present feel to be involved in it. Everywhere I find conditions which speak in favour of the specificity of leprosy, nothing whatever which distinctly contradicts it, and absolutely nothing which speaks in favour of non-specificity.'

In the following years Armauer Hansen worked steadily with new investigations to prove with certainty that the rod-shaped bodies discovered really were the causative agent of leprosy. On Robert Koch's advice he stained his smears for a longer time, and in 1879 he discovered a staining technique by which it was easier to demonstrate Mycobacterium leprae. He made numerous vain attempts to find a method of cultivating the bacillus on artificial media, and he also tried to transfer the disease to animals and human beings. Having first tried several times to transfer leprosy to rabbits without result, he inoculated the eye of a woman suffering from the anaesthetic form of leprosy with material from a leprous nodule. ${ }^{14}$ Nothing happened, but he had not sought permission, and he was sentenced on $3 \mathrm{I}$ May 1880 to be deprived of his position as resident physician at the Bergen leprosy hospitals. ${ }^{14}$ In 1875 he had, however, been appointed medical officer for leprosy for the whole country, and he continued in this 


\section{Th. M. Vogelsang}

appointment to his death in 1912. The sentence was discussed animatedly and reprobated in most scientific circles in Norway. It was announced in court that the case had been submitted to the Director General of the Norwegian Health Department in advance. The Director General was of the opinion that the experiment had been carried out to contribute to a question of the utmost importance to science, the nation and the patients, and that it had been performed by a man who had already made considerable contributions to the question mentioned. The sentence, however, also states that an illustrious man has to yield obedience to the Norwegian laws and that the court has to protect every subject of the nation against encroachment from more influential individuals.

It is Armauer Hansen's great achievement to have been the first to suggest that a chronic disease may be caused by micro-organisms. He observed the leprosy bacillus in 1873 and had it distinctly stained for demonstration in 1879 , whereas the tuberculosis bacillus was not discovered until 1882, the typhoid bacillus in 1883 , the diphtheria and the comma bacillus in 1884 , the tetanus in 1886 , etc.

Armauer Hansen's discovery necessarily brought about changes in ideas not only as to the cause of leprosy, but also regarding the manner in which the disease could be brought under effective control. The Norwegian Leprosy Act of 1877 and the amended Act of 1885 are the fruits of his indefatigable endeavours. By these laws the health authorities could order lepers to live in precautionary isolation away from their families. Exceptions were, however, made for married couples who desired to live together. In spite of this lenity, the law aroused violent opposition. However, in view of the excellent results derived from these precautionary health regulations, the opposition against the law gradually ceased. The Norwegian Leprosy Act has later served as model for leprosy legislation in many other countries.

After the enforcement of the Leprosy Act the disease declined in Norway quickly and steadily. While in 1856 there were 2,858 known cases of leprosy in Norway, and in $1875,1,752$, the number at the commencement of the new century dropped to $577 .^{10}$ This rapid decline gradually led to fewer admissions of new cases to the leper hospitals, and enabled some of them to cease being leper hospitals. As early as 1891 a brother of Armauer Hansen, Klaus Hansen, the founder of the Norwegian National Association against Tuberculosis, moved a motion that St. Jörgen's hospital's revenues should be used to build a hospital for consumptives. The Norwegian Parliament accepted this proposal. From 1896 new cases were not admitted to St. Jörgen's Hospital, but the lepers who were there at that time continued to live there until their death. The hospital's revenues were used to build a tuberculosis hospital which was opened in I902. However, the number with this disease also declined so much after the last war that a few years ago the tuberculosis hospital was transformed into a mental hospital.

In this century the number of lepers has continued to decline rapidly. In I910 the number dropped to 326 , in 1920 to 160 , in 1930 to 69 , and the decline has steadily continued. The last two lepers at St. Jörgen's Hospital died at about the 
same time in 1946 . Since then the hospital has been empty. Lately a notion has arisen to organize a historical medical museum in St. Jörgen's Hospital with the history of leprosy as the central theme.

In 1957 there were only seven lepers registered in Norway. The office of medical officer for leprosy was therefore abolished and the last leper hospital in Norway was transformed into a rehabilitation centre.

Although comprehensive scientific work in the bacteriology and epidemiology of leprosy has been carried out, there are still gaps in our knowledge. Nobody has yet succeeded in cultivating the leprosy bacillus, and there are still unknown factors with regard to the spread of the disease. On the other hand, the precautions taken have been successful. Leprosy is pre-eminently a disease of poverty-and the hygienic conditions and the economic welfare in Norway have increased considerably in this century. The last registered case of leprosy in Norway was discovered in 1953. There are at present only seven lepers alive in the whole country. Leprosy may therefore be regarded as practically stamped out in Norway today.

\section{REFERENCES}

I. We y мочтн, A., Through the Leper-Squint, London, I938, p. 240.

2. BugGe, A., Vikingerne, Köbenhavn og Kristiania, I, 1904; II, 1906.

3. WeYmouth, A., op. cit., p. 53.

4. FAYE, L., Hospitaler og milde Stiftelser i Norge i Middelalderen, Norsk Mag. f. Lagev, 1882, 12, 93-125 \& 181-228.

5. St ANG, F., St. Förgens hospital i Bergen, Kristiania, 1895 .

6. Mölle R-Christensen, V., Lepra og dens historie, Medicinsk Arbog, 1961/62, I 7-8I.

7. Petersson, M., Sankt Jörgen i Åhus. K. Humanistika Vetenskapssamfundets i Lund Arsberättelse 1947-1948, pp. 19I-257.

8. Richards, P., Leprosy in Scandinavia, Centaurus, 1960, 7, IoI-33.

9. Welmaven, G., Johan Ernest Welhaven og de Spedalske, Samtiden, 1941, 52, 593-4.

10. Vogelsang, Th. M., The termination of leprosy in Norway, Internat. $\mathcal{F}$. Leprosy, 1957, 25, 345-9.

II. Brungh ORST, J., D. C. Danielssen, Bergen Museums Årbok, I893, pp. I-6i.

12. Hansen, G. A., Bidrag til Lymphekjertlernes normale og patologiske Anatomi, Christiania, 1871 .

13. - Undersökelser angående Spedalskhedens Årsager, Norsk Mag. f. Lägev, 1874, 3, Rekke, Hefte 9.

14. Vogelsang, Th. M., A serious sentence passed against the discoverer of the leprosy bacillus (Gerhard Armauer Hansen), in 1880, Med. Hist., 1963, 7 182-6. 